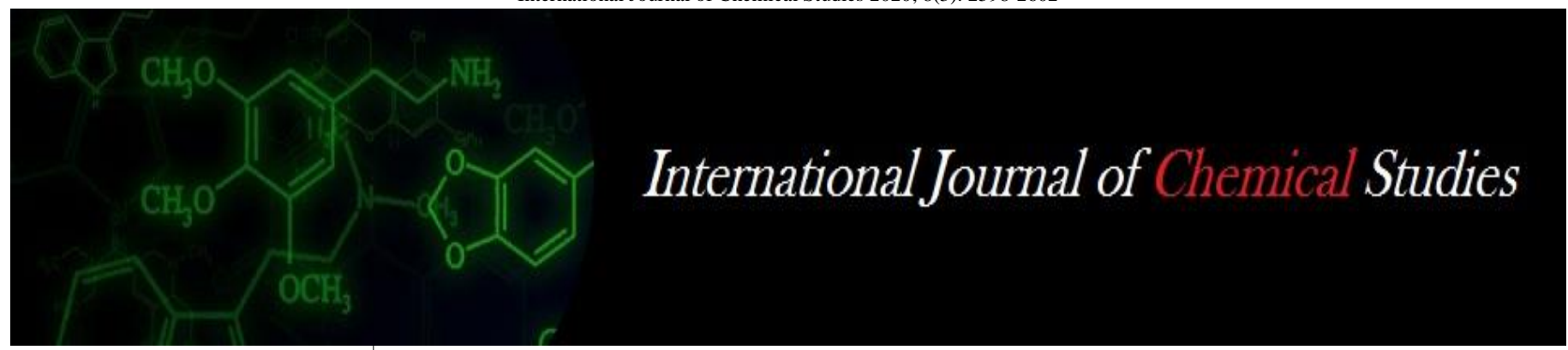

P-ISSN: 2349-8528

E-ISSN: 2321-4902

www.chemijournal.com

IJCS 2020; 8(3): 2598-2602

(C) 2020 IJCS

Received: 18-03-2020

Accepted: 22-04-2020

\section{Poornima Devi}

Department of Fruit Science,

College of Horticulture, C.S.A.

University of Agri. and

Technology Kanpur, Uttar

Pradesh, India

\section{JP Singh}

Department of Fruit Science,

College of Horticulture, C.S.A.

University of Agri. and

Technology Kanpur, Uttar

Pradesh, India
Corresponding Author:

\section{Poornima Devi}

Department of Fruit Science,

College of Horticulture, C.S.A.

University of Agri. and

Technology Kanpur, Uttar

Pradesh, India

\section{Effect of growth regulators and rooting media on the regeneration of Kagzi lime (Citrus aurantifolia Swingle) through air layering}

\section{Poornima Devi and JP Singh}

DOI: https://doi.org/10.22271/chemi.2020.v8.i3ak.9604

\begin{abstract}
The present investigation was undertaken to study the "Effect of growth regulators and rooting media on the regeneration of kagzi lime (Citrus aurantifolia Swingle) through air layering" at the Horticulture Garden, Department of Fruit Science, Chandra Shekhar Azad University of Agriculture and Technology Kanpur (U.P.) during the rainy season of 2018-19 and 2019-20. The experiment was laid out in a Factorial C.R.D. with replication trice. Twenty treatments two levels each of IBA and NAA (2000 ppm and $4000 \mathrm{ppm}$ ) and four rooting media i.e. soil, F.Y.M., vermicompost and moss grass were taken and these rooting media were also taken as unit of control. Data on all root parameters i.e. callus formation, days required for root initiation, number of primary roots, length of primary roots, diameter of primary roots, fresh weight of primary roots, dry weight of roots and percent of rooting were taken. IBA 4000 ppm was found significantly more effective and all above root characters revealing subsequently 0.59 , $0.61 \mathrm{~cm} ; 22.87,22.46$ days; $19.35,20.41 ; 4.58,4.66 \mathrm{~cm} ; 1.62,1.66 \mathrm{~mm} ; 4.39$ and $4.53 \mathrm{~g} ; 0.52,0.53 \mathrm{~g}$ and $80.59,82.55 \%$ values respectively. Rooting media moss grass proved superior among all the media maximizing all the above traits and recording $0.63,0.64 \mathrm{~cm} ; 22.17$ and 21.71 days; $21.38,22.47 ; 4.70$, $4.79 \mathrm{~cm} ; 1.67$ and $1.72 \mathrm{~mm} ; 4.83,5.05 \mathrm{~g} ; 0.57,0.49 \mathrm{~g}$ and 86.01, 88.03; values respectively during corresponding years. Combined effect of growth regulators and rooting media did not prove significant on all the root parameters barring percent of rooting. In this regard interactive treatment IBA $4000 \mathrm{ppm} \times$ moss grass enhanced rooting $(90.33$ and $92.02 \%)$. Control versus treatment varied significantly in all rooting characters during both the years of study.
\end{abstract}

Keywords: IBA, NAA, vermicompost, moss grass, Kagzi lime and root parameters

\section{Introduction}

The kagzi lime a native of India is an important citrus crop grown on commercial scale for multipurpose in India. It belongs to family Rutaceae and has very wide distribution in all the parts of India. It has very good refreshing value to eat and gives us very fair amount of vitamin-C, minerals and other substances for human health. It is also used for pickles, preparation of refreshing drinks, seasoning foods, citrate of lime and cosmetics, etc. In vegetative propagation air layering is used commercially and seems to be rather an easy method of propagation. Its vegetative propagation by air layering ensures true type plants, regular bearing and uniform quality. According to Loach (1988) ${ }^{[14]}$, the rooting media is an integral part of propagation system, percentage rooting and the quality of root produced are directly influenced by the medium (Hartmann et al. 2002) ${ }^{[11]}$. Auxins play a vital role in plant propagation, particularly IBA and NAA have been tried to induce rooting in various forms with varied success. These growth regulators than others were found better for inducing rooting in cutting and air layering due to their stable and non-toxic nature, the information of rooting media and growth substances on Kagzi lime air layering is yet scanty. The present study in view of the above was planned to find out the concrete role of growth regulators their optimal concentration and rooting media on the rooting attributes of Kagzi lime.

\section{Method and Materials}

The experiment was conducted during rainy season of 2018-19 and 2019-20 at the Horticulture Garden of Department of Fruit Science, C.S.A. University of Agriculture and Technology Kanpur- 208002 (U.P.). The experiment was conducted in Factorial C.R.D. with twenty treatments under three replications. 
The growth regulators i.e. IBA and NAA each in two concentrations i.e. $2000 \mathrm{ppm}$ and $4000 \mathrm{ppm}$ and four rooting media i.e. soil, F.Y.M., vermicompost and moss grass were tried. Plot size comprised twenty layers for each treatment. Layering operation was done on one year old branches having pencil thickness and the bark was removed $4 \mathrm{~cm}$ around the shoots. It was ensured that cambium was removed fully. IBA and NAA hormones as above respective concentration were prepared in talc powder. All the treatments were applied evenly around the ring out portion with the help of hand and wrapped with polythene 100 gauge and tied with the help of rope. The layering was done on 10 July 2018 and 2019 and separated and planted on 10 September of respective years. Pre-planting observations i.e. callus formation, days required for root initiation, number of primary roots, length of primary roots, diameter of primary roots, fresh weight of primary roots, dry weight of primary roots and per cent of rooting were recorded by routine methods.

\section{Results and Discussion}

IBA $4000 \mathrm{ppm}$ concentration proved significantly more effective recorded maximum $0.59 \mathrm{~cm}$ and $0.61 \mathrm{~cm}$ callusing against minimum 0.47 and $0.48 \mathrm{~cm}$ under 2000 ppm NAA during 2018 and 2019 respectively (Table-1). In size of callusing was observed by 25.53 and $27.08 \%$ due to IBA 4000 ppm over 2000 ppm NAA. The superiority of IBA may be attributed to enhance of synthesized food materials including carbohydrate accumulation in the plants which encourages quick healing and better callusing. These finding are in line with the reports of Sanchezurdaneta (2009) ${ }^{[25]}$ in guava. Moss grass caused significantly longest callus measuring 0.63 and $0.64 \mathrm{~cm}$ which revealed 46.51 and $45.45 \%$ increase than soil during respective years. Moss grass could have promoted higher content of air, moisture and suitable $\mathrm{pH}$ of media which led callusing. The findings are in line with the reports of Hartmann and Kester (1986) ${ }^{[10]}$. Interactive effect of growth regulators and rooting media did not touch level of significance (Table-2). Similarly, influence within controls was found to be non-significant during respective years. Control versus treatment showed significant variation during both the years of study (Table-1). The former recorded 0.32 and $0.34 \mathrm{~cm}$ against the later $(0.52$ and $0.53 \mathrm{~cm})$ during respective years of study being 62.50 and $55.88 \%$ more callusing due to treatment over control during corresponding years.

IBA 4000 ppm significantly induced earliest root initiation taking 22.87 and 22.46 days against the delayed initiation noted 25.53 and 25.12 days under 2000 ppm NAA during respective years. Thus, it was 10.41 and $10.59 \%$ earlier respectively during respective years. Haising (1971) [9] reported that root initials in stem are dependent upon native auxin and its synergism. Results talied with the reports of Baghel et al. (2016) ${ }^{[3]}$ and Naithini et al. (2018) in guava and Chawla et al. (2012) ${ }^{[4]}$ in litchi. Moss grass proved most effective exhibiting earliest (22.17 and 22.71 days) root initiation against the most delayed (26.53 and 26.11 days) noted under soil. In this respect moss grass caused 4.36 and 4.40 days earlier root initiation than soil during respective years. It have moss grass contain large amount of water in its cell and small amount of minerals and $\mathrm{pH}$ about 3.5 to 4.00, therefore, it could have played effective role in rooting. These findings are in line with the reports of Reddy et al. (2014) [22] in fig and Naik et al. (2016) ${ }^{[17]}$ in guava. Effect within control did not touch level of significance and interaction between growth regulators and rooting media was also non- significant. Control versus treatment revealed significant influence showing 28.90, 28.42 days and 24.47, 24.02 days requirement in this regard.

Production of primary roots (19.35 and 20.41) was significantly higher with IBA 4000 ppm against the lowest 15.81 and 16.91 exhibited with NAA 2000 ppm. In this parameter an improvement was recorded by 22.39 and $20.70 \%$ with IBA $4000 \mathrm{ppm}$. The findings are similar with the reports of Dubey and Yadav (2003) ${ }^{[8]}$ in orange, Lalramhluna and Prasad (2016) ${ }^{[13]}$ in lemon and Vyas et al. (2017) ${ }^{[30]}$ in red jamun. When efficacy of rooting media was judged moss grass excelled others during both the years recording 21.38 and $22.47 \%$ primary roots against the minimum of 14.16 and 15.24 under soil. Thus, there was an increase of 50.99 and $47.44 \%$ due to moss grass over soil. In addition to the above desirable abilities of moss grass its light weight gives water holding capacity and low $\mathrm{pH}$. These findings are in with the reports of Shajh et al. (2013) ${ }^{[25]}$ in olive, Naik et al. (2016) ${ }^{[17]}$ and Das et al. (2016) ${ }^{[7]}$ in litchi. Interactive treatments did not cause significant variation in this contest (Table-2). Similarly, all the four unit of control did not bring significant variation. Control versus treatment varied significantly during both years producing $11.73,12.78$ and $17.28,18.35$ numbers of primary roots respectively.

As regards the length of root IBA 4000 ppm produced longest of it $(4.58$ and $4.66 \mathrm{~cm})$ roots against the shortest $(4.11$ and $4.19 \mathrm{~cm}$ ) recorded NAA $2000 \mathrm{ppm}$. The root length 11.44 and $11.22 \%$ greater was due to IBA 4000 ppm treatment during respective years. It may be due to the role of IBA in cell elongation as well as cell division which are apparently dependent on endogenous auxin and when applied exogenously it enhanced length of primary roots in present investigation. These findings are in close conformity with the reports of Tyagi and Patel (2004) ${ }^{[28]}$, Manker et al. (2009) ${ }^{[15]}$ and Naithani et al. (2018) ${ }^{[18]}$ in guava. Moss grass media proved effective and promoted $(4.70$ and $4.79 \mathrm{~cm})$ length of primary root to the maximum against the smallest (3.96 and $4.03 \mathrm{~cm}$ ) noted under soil. An increase of 18.89 and $18.86 \%$ in this respect was observed under moss grass over soil media during respective years. The superiority of moss grass might be owing to its unique ability to enhance rooting along with root elongation. Similar result has been reported by Das et al. (2016) ${ }^{[7]}$ in litchi and Naik et al. (2016) ${ }^{[17]}$ in guava. Treatment versus control demonstrated significant differences recording $4.29,4.37 \mathrm{~cm}$ and $3.62,3.70 \mathrm{~cm}$ root length respectively.

Quite like root length the diameter was also boosted by treatment IBA $4000 \mathrm{ppm}$ which showed significantly maximum $(1.62$ and $1.66 \mathrm{~mm}$ ) against the thinnest diameter (1.42 and $1.47 \mathrm{~mm})$ recorded under $2000 \mathrm{ppm}$ NAA. The diameter was improved by 14.08 and $12.93 \%$ with IBA 4000 ppm over NAA 2000 ppm during respective years. The superiority brought about by higher concentration of IBA may be ascribed to its efficacy in cell division as well as elongation. These findings are in agreement with the reports of Jan et al. (2012) and Das and Prasad (2014) ${ }^{[6]}$ in litchi, Tyagi and Patel (2004) ${ }^{[28]}$ and Naithani et al. (2018) ${ }^{[18]}$ in guava. When the effect of rooting media was examined thickest diameter 1.67 and $1.72 \mathrm{~mm}$ were produced under the moss grass and thinnest under soil (1.34 and $1.38 \mathrm{~mm})$ during corresponding years of study. An enhancement in diameter by 24.63 and $24.65 \%$ was noted due to moss grass over soil. In the present investigation improvement in number of root and leaves ultimately led to carbohydrate accumulation whose response positively increased the diameter. These findings are 
in accordance with the reports of Rymbai and Reddy (2012) ${ }^{\text {[24] }}$, Parmar et al. (2018) ${ }^{[19]}$ in guava and Patel et al. (2012) ${ }^{[20]}$ in pomegranate. Interactive effect of growth regulator and rooting media were found non-significant. Control versus treatment however brought about significant differences causing 1.50 and $1.54 \mathrm{~mm}$ diameter with treatment against 1.16 and $1.20 \mathrm{~mm}$ recorded under control respectively during corresponding years.

The fresh weight of roots with IBA $4000 \mathrm{ppm}$ treatment to improved significantly maximum (4.39 and $4.53 \mathrm{~g})$ against the minimum under 2000 ppm NAA (3.91 and $4.07 \mathrm{~g}$ ) during both corresponding years. The former caused an increase of 12.28 and $11.30 \%$ over the later. In present study acceleration of root formation as well as strengthening them ultimately improved fresh weight of roots. These findings are in line with the reports of Ray et al. (2001) [21], Jan et al. (2003) ${ }^{[12]}$ and Das and Prasad (2014) ${ }^{[6]}$ in litchi, Chovatia and Singh (2000) [5] in sweet orange and Patel et al. (2012) ${ }^{[20]}$ in pomegranate. Rooting media differed significantly in root production in term of their weight under moss grass gave the maximum 4.83 and $5.05 \mathrm{~g}$ fresh weight of root against the minimum in soil (3.51 and $3.63 \mathrm{~g}$ ). A comparison of the above showed 37.61 and $38.84 \%$ improvement in this parameter was observed it is obviously due to high moisture retaining capacity, porocity and optimum $\mathrm{pH}$ of moss grass (Hartmann and Kester, 1986) ${ }^{[10]}$. The findings are in accordance with the reports of Singh and Pandey (2009) ${ }^{[26]}$ in guava and Mishra (2014) ${ }^{[16]}$ in Kagzi lime. Control versus treatment exhibited significant differences recording 3.04, $3.29 \mathrm{~g}$ and $4.12,4.30 \mathrm{~g}$ fresh weight of root respectively.

The dry weight content of root was noted significantly highest under IBA $4000 \mathrm{ppm}(0.52$ and $0.53 \mathrm{~g})$ against the lowest $(0.46$ and $0.46 \mathrm{~g})$ under NAA $2000 \mathrm{ppm}$. The former treatment increased it by 10.63 and $10.20 \%$ over the later. The increase may be attributed to the increased size and number of roots caused by exogenous application of IBA 4000 ppm. These findings also form similar results with the reports of Tyagi and Patel (2004) ${ }^{[28]}$ and Baghel et al. (2016) ${ }^{[3]}$ in guava and Das and Prasad (2014) ${ }^{[6]}$ in litchi. Moss grass induced significantly maximum $(0.57$ and $0.60 \mathrm{~g})$ dry weight of roots and minimum of it $(0.41$ and $0.43 \mathrm{~g})$ noted under soil media. An increase in dry weight of primary roots was achieved by 39.02 and $39.53 \%$ due to moss grass over soil during respective years. This enhancement may be attributed to accumulation of food materials as well as larger root length and change in amino acid metabolism which ultimately favored dry matter accumulation. These results collaborate with the observation of Awan et al. (2000) ${ }^{[2]}$ in litchi, Singh et al. (2007) in guava and Reddy et al. (2014) ${ }^{[23]}$ in fig. Comparison of control versus treatment exhibited significant differences revealing $0.36,0.39 \mathrm{~g}$ and $0.48,0.51 \mathrm{~g}$ dry weight respectively. Treatments increased it to the tune of 33.33 and $30.77 \%$ over control during corresponding years of study.

The rooting at $4000 \mathrm{ppm}$ IBA treatment significantly maximized (80.59 and $82.55 \%)$ during respective years. Lower concentration irrespective of growth regulators proved relatively less effective and recorded 66.24 and 72.13 per cent rooting when compared with IBA 2000 ppm during respective years (Table-1). Rooting enhanced by 21.66 and $14.45 \%$ with IBA $4000 \mathrm{ppm}$ concentration. It is obviously exogenous application of auxin which might have ultimately helped to promotion of rooting per cent. These finding are accordance with the reports of Anandhanmbi et al. (2016) ${ }^{[1]}$ and Naithani et al. (2018) ${ }^{[18]}$ in guava. Moss grass revealing 86.01 and $88.03 \%$ rooting being significantly superior than rest of rooting media and exhibited 42.14 and $40.58 \%$ more rooting than soil during respective years. These findings are in line with the reports of Das et al. (2016) ${ }^{[7]}$ in litchi and Urmi et al. (2016) [9] in guava. Influence within unit of media varied significantly and recorded maximum i.e. 50.61 and $53.07 \%$ rooting against the minimum of 43.01 and $45.16 \%$ under soil during respective years. Treatment versus control brought about significant differences. Former revealed 72.10 and $75.53 \%$ rooting and the later 46.82 and $48.96 \%$ during corresponding years of study. Interactive treatment $\mathrm{I}_{2} \mathrm{R}_{4}$ revealed the maximum (90.33 and $92.02 \%$ ) rooting followed by $\mathrm{I}_{1} \mathrm{R}_{4}$ and $\mathrm{N}_{2} \mathrm{R}_{4}$ recording $87.83,89.94 \%$ and $83.89,85.98 \%$ rooting respectively. The minimum 53.66 and $55.61 \%$ rooting (Table-2) demonstrated under interactive treatment $\mathrm{N}_{1} \mathrm{R}_{1}$ during corresponding years of investigation.

Table 1: Effect of regulators, rooting media, controls and treatment v/s control on different root attributes in Kagzi lime air layers

\begin{tabular}{|c|c|c|c|c|c|c|c|c|c|c|c|c|c|c|c|c|}
\hline \multirow[t]{2}{*}{ Treatments } & \multicolumn{2}{|c|}{$\begin{array}{c}\text { Callus } \\
\text { formation } \\
(\mathrm{cm})\end{array}$} & \multicolumn{2}{|c|}{$\begin{array}{c}\text { Days required } \\
\text { for root } \\
\text { initiation } \\
\end{array}$} & \multicolumn{2}{|c|}{$\begin{array}{c}\text { Number of } \\
\text { primary roots }\end{array}$} & \multicolumn{2}{|c|}{\begin{tabular}{|c|}
$\begin{array}{c}\text { Length of } \\
\text { primary roots } \\
(\mathrm{cm})\end{array}$ \\
\end{tabular}} & \multicolumn{2}{|c|}{\begin{tabular}{|c}
$\begin{array}{c}\text { Diameter of } \\
\text { primary roots } \\
(\mathrm{mm})\end{array}$ \\
\end{tabular}} & \multicolumn{2}{|c|}{\begin{tabular}{|c|}
$\begin{array}{c}\text { Fresh weight of } \\
\text { primary roots } \\
\text { (g) }\end{array}$ \\
\end{tabular}} & \multicolumn{2}{|c|}{$\begin{array}{l}\text { Dry weight of } \\
\text { primary roots } \\
\text { (g) }\end{array}$} & \multicolumn{2}{|c|}{$\begin{array}{l}\text { Per cent of } \\
\text { rooting }(\%)\end{array}$} \\
\hline & $\begin{array}{c}2018- \\
19\end{array}$ & $\begin{array}{c}2019- \\
20\end{array}$ & 2018-19 & 2019-20 & \begin{tabular}{|c}
$2018-$ \\
19
\end{tabular} & $\begin{array}{c}2019- \\
20\end{array}$ & $\begin{array}{c}2018- \\
19\end{array}$ & $\begin{array}{c}2019- \\
20\end{array}$ & 2018-19 & م2 & & $2019-20$ & $\begin{array}{c}2018- \\
19\end{array}$ & $\begin{array}{c}2019- \\
20\end{array}$ & $\begin{array}{c}2018- \\
19\end{array}$ & $\begin{array}{c}2019- \\
20\end{array}$ \\
\hline $\mathrm{I}_{1}$ & 0.50 & 0.51 & 24.94 & 24.45 & 16.48 & 17.56 & 4.24 & 4.32 & 1.46 & 1.50 & 3.99 & 4.18 & 0.47 & 0.49 & 69.67 & 72.13 \\
\hline $\mathrm{I}_{2}$ & 0.59 & 0.61 & 22.87 & 22.46 & 19.35 & 20.41 & 4.58 & & 1.62 & 1.66 & 4.39 & & & 0.54 & & 82.55 \\
\hline $\mathrm{N}_{1}$ & 47 & 48 & 25.53 & 25.12 & & & 4.11 & & 1.42 & 1.47 & & & & & & 3.34 \\
\hline $\mathrm{N}_{2}$ & 0.52 & 0.53 & 24.54 & 24.06 & 17. & 18.52 & 4.24 & 4.32 & 1.49 & 1.53 & & & & 52 & 71.91 & 74.11 \\
\hline $\mathrm{R}_{1}$ & 0.43 & 0.44 & 26.53 & 26.83 & & & 3.96 & & 1.34 & 1.38 & & & & & & 62.62 \\
\hline $\mathrm{R}_{2}$ & 0.48 & 0.50 & 25.18 & 24.52 & 15.55 & 16.26 & 4.14 & 4.22 & 1.44 & 1.48 & & & & 0.51 & & 75.03 \\
\hline $\mathrm{R}_{3}$ & 0.53 & 0.55 & 24.01 & 22.80 & & & 4.36 & & 1.53 & 1.58 & & & & & & 76.46 \\
\hline & 63 & 0.6 & 22. & & & & 4.70 & 9 & 1.6 & 1.7 & & & & & & 88.03 \\
\hline $\mathrm{C}_{1}$ & 0.29 & 0.31 & 29.60 & 29.12 & 11. & 2.10 & 3.52 & 3.59 & 1.11 & 1.15 & 2.9 & & 4 & 37 & 01 & 45.16 \\
\hline $\mathrm{C}_{2}$ & 0.32 & 0.33 & & 28.60 & & & 3.58 & 3.66 & 1.14 & 1.18 & 3.1 & & & 39 & 57 & 47.22 \\
\hline $\mathrm{C}_{3}$ & 34 & 0.35 & 28.66 & 28.21 & & & 3.65 & 3.74 & 1.1 & 1.21 & 2. & & & & & 50.39 \\
\hline $\mathrm{C}_{4}$ & 0.35 & 0.37 & 28.22 & 27.76 & & & 3.73 & 3.80 & 1.22 & 1.25 & 3.2 & & & & & 53.07 \\
\hline $\mathrm{T}$ & 52 & & & & & & 4.29 & & 1.50 & & & & & & & 75.53 \\
\hline $\mathrm{C}$ & 32 & 34 & 28.90 & 28.42 & & .78 & 3.62 & 3.70 & 1.16 & 1.20 & 3.1 & & & & & 48.96 \\
\hline \multicolumn{17}{|l|}{ C.D. at $5 \%$} \\
\hline $\mathrm{G}$ & 05 & 0.05 & & & & 1.50 & 0.19 & 0.21 & 0.11 & 0.12 & 0.2 & & & 0.05 & 2.29 & 2.49 \\
\hline $\mathrm{R}$ & 0.05 & 0.05 & & & & & 0.19 & 0.2 & 0.11 & 0.12 & 0. & & 0.1 & 0.05 & .29 & 2.49 \\
\hline Within control & N.S. & N.S. & & & & & N.S. & & N.S. & N.S. & & & & & & 4.99 \\
\hline Treatment v/s & 0.02 & 0.02 & 0.44 & 0.61 & 0.61 & 0.65 & 0.08 & 0.09 & 0.05 & 0.05 & 0.09 & 0.10 & 0.02 & 0.02 & 1.00 & 1.09 \\
\hline
\end{tabular}


control

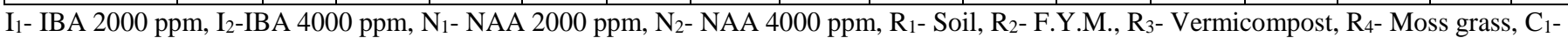
Unit of control (soil), $C_{2}$ - Unit of control (F.Y.M.), $\mathrm{C}_{3}$ - Unit of control (Vermicompost), C4- Unit of control (Moss grass), G- Growth regulator,

R- Rooting media

Table 2: Interactive effect of growth regulators and rooting media on different root attributes in kagzi lime air layers

\begin{tabular}{|c|c|c|c|c|c|c|c|c|c|c|c|c|c|c|c|c|}
\hline \multirow[t]{2}{*}{ Treatments } & \multicolumn{2}{|c|}{$\begin{array}{c}\text { Callus } \\
\text { formation } \\
(\mathbf{c m})\end{array}$} & \multicolumn{2}{|c|}{$\begin{array}{c}\text { Days required } \\
\text { for root } \\
\text { initiation } \\
\end{array}$} & \multicolumn{2}{|c|}{$\begin{array}{c}\text { Number of } \\
\text { primary roots }\end{array}$} & \multicolumn{2}{|c|}{$\begin{array}{c}\begin{array}{c}\text { Length of } \\
\text { primary roots } \\
(\mathrm{cm})\end{array} \\
\end{array}$} & \multicolumn{2}{|c|}{$\begin{array}{c}\text { Diameter of } \\
\text { primary roots } \\
(\mathrm{mm})\end{array}$} & \multicolumn{2}{|c|}{$\begin{array}{c}\text { Fresh weight of } \\
\text { primary roots } \\
\text { (g) }\end{array}$} & \multicolumn{2}{|c|}{$\begin{array}{l}\text { Dry weight of } \\
\text { primary roots } \\
\text { (g) }\end{array}$} & \multicolumn{2}{|c|}{$\begin{array}{l}\text { Per cent of } \\
\text { rooting }(\%)\end{array}$} \\
\hline & $\begin{array}{c}2018- \\
19\end{array}$ & 2019-20 & 2018-19 & $\begin{array}{c}2019- \\
20 \\
\end{array}$ & $\begin{array}{c}2018- \\
19 \\
\end{array}$ & \begin{tabular}{|c|}
$2019-$ \\
20 \\
\end{tabular} & $\begin{array}{c}2018- \\
19 \\
\end{array}$ & $\begin{array}{c}2019- \\
20 \\
\end{array}$ & $\begin{array}{c}2018- \\
19 \\
\end{array}$ & $\begin{array}{c}2019- \\
20\end{array}$ & 2018-19 & 2019-20 & $\begin{array}{c}2018- \\
19 \\
\end{array}$ & $\begin{array}{c}2019- \\
20 \\
\end{array}$ & $\begin{array}{c}2018- \\
19 \\
\end{array}$ & $\begin{array}{c}2019- \\
20\end{array}$ \\
\hline & 0.42 & 0.42 & 26.88 & 26.39 & 13.77 & 14.73 & 3.91 & 3.98 & 1.32 & 1.36 & & & 0.40 & & & \\
\hline & & 0.44 & & & & & 3.98 & & & & & & & & & \\
\hline & & 0.52 & & & & & 4.23 & & & & & & & & & \\
\hline & & 0.66 & 1.81 & & & & 4.84 & & & & & & & & & 9.94 \\
\hline & & 0.54 & & & & & 4.29 & & & & & & & & & \\
\hline & 54 & 0.56 & & 23.28 & & & 4.33 & & 1 & & & & & & & 7.97 \\
\hline & & & & & & & 4.7 & & & & & & & & & \\
\hline & & & & & & & 4.9 & & & & & & & & & \\
\hline & & 0.39 & & 51 & & & 3.79 & & 1.25 & 28 & & 3. & & & 66 & 55.61 \\
\hline & 47 & 0.48 & & 25.06 & & & 4.11 & & 1.4 & 1.46 & & 4. & & & & 87.87 \\
\hline & & 0.46 & 25.98 & 25.44 & & & 4.05 & & 1.3 & & & & & & & 65.70 \\
\hline & & & & & & & & & & & & & & & & \\
\hline & & 0.41 & 27.31 & 26.33 & & & 3.84 & & 1.28 & & 3.4 & 3.68 & & & 26 & 58.46 \\
\hline & 50 & 0.51 & 25.04 & 24.52 & & & 4.16 & & 1.45 & & & 4.70 & & & 01 & 70.41 \\
\hline & 56 & 0.58 & 23.31 & 22.80 & 20. & & 4.39 & 4.48 & 1.59 & 1.62 & 3.9 & 4.22 & 0.5 & 52 & 79.48 & 81.59 \\
\hline & 61 & 0.63 & 22.52 & 22.10 & 20.91 & & 4.57 & & 1.64 & 1.68 & 4.68 & 4.91 & 0.55 & & 83.89 & 85.98 \\
\hline D. at $5 \% \mathrm{G} \times \mathrm{R}$ & N.S. & N.S. & N.S. & N.S. & N.S. & N.S. & N.S. & N.S. & N.S. & N.S. & N.S. & N.S. & N.S. & N.S. & 4.58 & 4.99 \\
\hline
\end{tabular}

\section{References}

1. Anandhanambi D, Arivazhagan E, Kandasamy R. Influence of plant growth regulators and Azospirillum on rooting of air layers in guava (Psidium guajava L.). The Asian Journal of Horticulture. 2016; 11(2):261-268.

2. Awan AA, Hussain I, Noor Rehman N, Jane A, Ali N. Effect of different media and timing factor on rooting of litchi (Litchi chinensis) plant through air layering. Pakistan Journal of Biological Sciences. 2000; 3(11):1809-1810.

3. Baghel M, Raut UA, Ramteke V. Effect of IBA concentrations and time of air-layering in Guava $c v$. L49. Research Journal of Agricultural Sciences. 2016; 7(1):117-120.

4. Chawla W, Mehta K, Chauhan N. Influence of plant growth regulators on rooting of litchi (Litchi chinensis Sonn.) air layers. The Asian Journal of Horticulture. 2012; 7(1):160-164.

5. Chovatia RS, Singh SP. Effect of ringing of shoots and treatment with IBA and NAA on success of air-layering in lasoda (Cordia dichotoma Forst.). Adv. For. Res. Indian. 2000; 22:173-181.

6. Das AK, Prasad B. Effect of plant growth regulators on rooting and survival of air layering in litchi. Advance Research Journal of Improvement. 2014; 5(2):126-130.

7. Das AK, Das S, Prasad B, Mehta S, Ranjan RD. Assessment of rooting media for enhancing survivability and profitability of air layering in Litchi. International Journal of Agriculture Sciences. 2016; 8(51):2260-2262.

8. Dubey AK, Yadav DS. Effect of NAA on rooting of air layers in different varieties of sweet orange. Orissa $\mathrm{J}$ Hort. 2003; 31(1):51-53.

9. Haising BE. Influence of Indole-3 acetic acid of incorporation of 14 , e-uridine by adventious root primordial in brittle willow. Hort. Gaz. 1971; 132(4):263267.
10. Hartmann HT, Kester DE. Plant propagation: Principles and Practices. $4^{\text {th }}$ edition, Prentice Hall of India Private Limited, New Delhi, 1986.

11. Hartmann HT, Kester DE, Davies FT, Geneve RL. Techniques of propagation by cuttings. In: Plant Propagation: Principles and Practices. 6th ed., Prentice Hall of India, Pvt. Ltd., New Delhi, 2002, 321.

12. Jan NE, Wazir, Mohammad, Ishtiaq Haji FK, Ali Mohammad Asghar. Effect of different concentrations of IBA on rooting of litchi in air layering. Sarhad Journal of Agri. 2003; 19(1):47-54.

13. Lalramhluna, Peter, Prasad VM. Effect of Different Levels of Indole-3-butyric acid on growth, development, survival and establishment of air layered lemon (Citrus limon L. Burm.) Cv. Assam Lemon under Allahabad agro-climatic condition. International Journal of LifeSciences Scientific Research. 2016; 2(5):599-603.

14. Loach. Controlling environment conditions to improve adventitious rooting. In: Adventitious root formation in cuttings (Davis, T.D.,Haissig, B.E. and Sankhla N., eds.) Dioscorides Press, Porland, Oregon, 1988, 248-279.

15. Mankar JM, Wankhade RS, Bhople SR. Effect of some plant growth regulators on rooting and survival of layerage in guava. Annals of Plant Physiology. 2009; 23(2):192-195.

16. Mishra S. Effect of different rooting media on survival and success of air layers in kagzi lime. Annals of Plant and Soil Research. 2014; 16(3):264-267.

17. Naik R, Patil SN, Gandolkar K, Mesta R, Goudappanavar B, Naik J, Naik A. Effect of organic rooting media on success of air layering in guava. Res. Environ. Life Sci. 2016; 10(2):135-138.

18. Naithani DC, Nautiyal AR, Rana DDK, Mewar D. Effect of time of air layering and IBA concentrations on the rooting behaviour of pant prabhat guava (Psidium guajava L.) under sub-tropical condition of Garhwal 
Himalaya. Journal of Plant Development Sciences. 2018; 10(1):49-54.

19. Parmar JP, Tiwari R, Gautam KK, Yadav L, Upadhyay $\mathrm{N}$. Effect of Indole 3-butyric acid (IBA), rooting media and their interaction on different rooting and growth characteristic of air-layers in guava (Psidium guajava L. cv. L-49). Journal of Applied and Natural Science. 2018; 10(1):241-246.

20. Patel DM, Nehete DS, Jadav RG, Satidiya BN. Effect of PGRs and rooting media on air layering of different pomegranate (Punica granatum L.) cultivars. Asian J Hort. 2012; 7(1):89-93.

21. Ray RN, Dwivedi AK, Rao PS, Jain BP. Effect of IBA and coloured wrapping material on propagation of litchi (Litchi chinensis Sonn.) cv. Purbi. Haryana J Horti. Sci. 2001; 30(3-4):170-172.

22. Reddy PPN, Ray NR, Patel AD, Patel JS. Effect of rooting media and IBA (Indole butyric acid) levels on rooting and survival of air layering in fig (Ficus carica L.) cv. Poona under middle Gujarat agro-climatic conditions. The Asian Journal of Hort. 2014; 9(1):1-5.

23. Rymbai H, Reddy GS. Effect of IBA, time of layering and rooting media on air layers and plantlets survival under different growing nursery conditions in guava. Indian J Horti. 2010; 67:99-104.

24. Sanchezurdaneta AB, Suarez E, Gonzalez RM, Amaya Y, Colmenares CB, Ortega J. Effect of IBA on the air layer rooting of guava (Psidium guajava L.) in the Baralt County, Venezuela. Preliminary evaluation. Revista UDO Agricola. 2009; 9(1):113-120.

25. Shajh AH, Awan AA, Hammad Ali. Response of olive cultivar to rooting through air layering in different growth media. Sarhad journal of Agri. 2013; 29(1):1-5.

26. Singh BV, Pandey SK. Influence of growth regulators and rooting media medium on promotion of root characters and survival of air layered guava shoots. Annal of Plant and Soil Research. 2009; 11(2):120-121.

27. Singh G, Awasthi P, Tiwari JP, Lal S. Effect of IBA and NAA on rooting potential of stooled shoots of Guava cv. sardar. Hort. Act., 735.

28. Tyagi SK, Patel RM. Effect of growth regulators on rooting of air layering of guava (Psidium guajava L.) cv. Sardar guava. Orissa J Hort. 2004; 32(1):58-62.

29. Urmi FF, Malek MA, Ali M, Rahman MS. Effect of operational time and rooting media on success and survivability of air layering in guava. J Patuakhali Sci. and Tech. Uni. 2016; 7(1\&2):1-10.

30. Vyas SV, Butani AM, Nurbhanej KH, Patel MS, Parmar LS. Effect of Time of Air Layering and IBA on Red Jamun (Syzygium samarangense L.) cv. Local. Int. J Pure App. Biosci. 2017; 5(5):272-279. 